\title{
Do you Believe an Altman or Modified Altman Algorithm would be Effective as a Component of a Management Performance Measurement System? How so?
}

\section{Payal Chadha*}

Swiss Management Center, University Zug, Kuwait

Calandro [1] stated that Altman's Z-score could be a good source for analyzing financial performance of an organization by testing its distress level. The Z-score model has been accepted as a financial distress model for almost four decades, leading in areas such as credit risk analysis, merger and acquisition target analysis, and turnaround management [1].

For credit risk analysis, the Z-score helps to score applicants that are applying for loans [2]. For merger and acquisition, the Z-score helps to recognize companies with severe cash problems. Stock brokers use this to determine if a company is a good investment for merging and acquiring [2].

For turnaround management, converting barren assets into cash is serious for reducing debt and primary successful turnaround [3]. Using computer simulation models and what-if analysis, the turnaround strategy can be depicted [3]. The Z-Score corresponds the action plan to the management by selling off assets for company's survival [3]. Management concludes what level of losses can sustain as part to produce cash through asset reduction [3].

For private firms, the $\mathrm{Z}$-score modified formula is: $\mathrm{Z}=6.56 \mathrm{X} 1+$ $3.26 \mathrm{X} 2+6.72 \mathrm{X} 3+1.05 \mathrm{X} 4$, where $\mathrm{X} 1=$ working capital/total assets; $\mathrm{X} 2=$ retained earnings/total assets; $\mathrm{X} 3=\mathrm{EBIT} /$ total assets; and $\mathrm{X} 4=$ net worth/total liabilities [1]. The criteria used to interpret the revised model are: Safe Zone $=Z>2.60$; Distress $Z$ Zone $=Z<1.10$; and Grey Zone $=1: 10<=\mathrm{Z}<=2.60[1]$.

For public firms, the $\mathrm{Z}$-score formula is: $\mathrm{Z}=1.2 \mathrm{X} 1+1.4 \mathrm{X} 2+3.3 \mathrm{X} 3$ $+0.6 \mathrm{X} 4+1.0 \mathrm{X} 5$, where $\mathrm{X} 1=$ working capital/total assets; $\mathrm{X} 2=$ retained earnings/total assets; $\mathrm{X} 3=\mathrm{EBIT} /$ total assets; $\mathrm{X} 4=$ market value of equity/ book value of total liabilities; and $X 5=$ sales/total assets. The criteria used to interpret the model are: Safe $Z$ one $=Z>2.99$; Distress $Z$ Zone $=Z$ $<1.81$; and Grey Zone $=1.81<=\mathrm{Z}<=2.99$ [1].

Pricewater Coopers conducted a study on 1,200 publicly owned manufacturing companies (1998-2001 data) concluded that the Z-score's presentation was steady with its historical results by $80-90$ percent accuracy one year prior to bankruptcy [4].

\section{Do you Believe Strassmann's 'Knowledge Management' Metric is an Important one? Why?}

Knowledge in a business framework falls within the range of implicit and explicit knowledge [5]. Tacit knowledge is within people and difficult to share, while explicit knowledge is captured and stored in manuals, procedures, and databases within organizations, and shared with others in the organization [5]. The role of Knowledge Management (KM) is to unfasten and influence the diverse types of knowledge to make it available as an organizational asset [5].

Every company is competing to survive in the market, just like Darwin's theory [6]. The service-based organizations are very close to the customer and their needs should be satisfied every time it arises [6]. It is a fairly pressurized kind of environment, and quite opportunistic.
The only thing that curbs this opportunism is the fact that members accumulate so much knowledge [6].

Strassman stated in an interview that in a service based organization, there are "diseconomies" of scale, in more capital, and in larger agglomerations. The real measure is return on people as they are the capital [6]. It is the accumulated knowledge of an organization that represents the competitive advantage [6]. Even though the cost structures today is moving towards technology, the volume of the cost is in people [6]. Strassman emphasized on the demand side as service needs are human needs, and so the focus should be on how people's needs be satisfied. As the needs increase, they become more intertwined and complex. With complexity, specialization increases in the hands of the few people who provide the infrastructure and the support [6]. The organization should be designed based on an analysis of the market that is being served [6].

The importance of the Strassmann's KM metric is based on the existence of original principles in organizations, which express sufficient links or associations among knowledge workers and extensively relate to the development of independent motivation towards KM usage [7]. In conclusion, the actual use of KM was found in competency development among knowledge workers at all levels of the organizations [7].

\section{References}

1. Calandro $\mathrm{J}$ (2007) Considering the utility of Altman's Z-score as a strategic assessment and performance management tool. Strategy \& Leadership 35: $37-43$.

2. Altman EI (1977) The z-score bankruptcy model: Past, present, and future. Financial Crises: Institutions and Markets in a Fragile Environment. Wiley, NewYork.

3. Lucarelli A (2003) Using the Z-Score as a turnaround tool.

4. Rufus R (2003) Financial ratios: use, predictive power and the Z-Score.

5. Carrillo PM, Robinson HS, Anumba CJ, Al-Ghassani AM (2013) IMPaKT: A framework for linking knowledge management to business performance. Electronic Journal of Knowledge Management 1: 1-12.

6. Zuboff S (1985) Conversation with Paul A. Strassmann. Organizational Dynamics 14: 19-34.

7. Haron A (2015) KPIs in a management measurement system must be supportive. Business and Economics Journal 6: 1-2.

*Corresponding author: Chadha P, Swiss Management Center, University Zug Kuwait, Tel: +96569078096; E-mail: payal.chad@gmail.com

Received May 10, 2016; Accepted June 25, 2016; Published June 30, 2016

Citation: Chadha P (2016) Do you Believe an Altman or Modified Altman Algorithm would be Effective as a Component of a Management Performance Measurement System? How so? Int J Account Res S1: 001. doi:10.4172/2472-114X.S1-001

Copyright: ( 2016 Chadha $P$. This is an open-access article distributed under the terms of the Creative Commons Attribution License, which permits unrestricted use, distribution, and reproduction in any medium, provided the original author and source are credited. 